\title{
Pedagogies of Indignation and The Lives of Others
}

\section{Introduction}

Critical Pedagogy has always had as part of its aim not just, as Henry Giroux states, to "illuminate[s] the relationships among knowledge, authority, and power" in educational settings. As an ongoing political project, it also addresses "the relationship between how we learn and how we act as individual and social agents; that is, it is concerned with teaching students how not only to think but to come to grips with a sense of individual and social responsibility." (Giroux, 2017). As such, it is part of the role of critical educators to try to reach, in their theoretical work and in the classroom, an informed, reflective and rich understanding of the meaning and complexity of moral agency and its intersection with questions of social and political change.

Philosophical work can inform this project in several ways. These include work in political philosophy that offers normative accounts of justice, democracy or equality, and work in epistemology and moral theory that explores the ethical and political aspects of our epistemic practices and the complex relationship between individual agency, identity, knowledge, ignorance, injustice and oppression. This work can enrich our discussions about the relationship, so central to critical pedagogy, between knowledge and experience, and social/political change. Yet in reflecting on these issues, it is important that we think not just about the political context of the relationships, ideas and individuals that populate schools and classrooms, but about the pedagogical relationships that go on elsewhere in our lives. Education is not the same as schooling, and there is value in exploring the moral and political significance of pedagogical spaces, processes and relationships outside the walls of institutions. In this context, I was glad to read Rebecca Tarlau's excellent recent paper on the need to bring together insights from Critical Pedagogy and Social Movement Theory (Tarlau, 2014). Tarlau quotes Jean Anyon, who calls for a synthesis between social movement and critical pedagogy literature, arguing that if this were to occur, "Critical pedagogy would take to the streets, offices, and courtrooms where social justice struggles play out." (Anyon, in Tarlau, 2014, p. 390)

As Tarlau's own work illustrates, this is not just a practical call for political activists to draw on the resources and experience of critical pedagogues, but a call for an intellectual dialogue between the insights offered by theorists of Critical Pedagogy and theorists of social movements so as to enrich our understanding of how collective movements for social change can mobilize activists, articulate motivating conceptions of justice, and effectively enact opposition and dissent.

However, in addition to the theoretical understanding of processes of mobilization and dissent offered by social movement theory, it is important that critical educators reflect, with themselves and with their students, on the personal, affective and epistemic aspects of the ways in which individual agents come to make ethically significant choices in conditions of political struggle. The philosophical questions here include not just questions of "what was the right choice to make?" but questions of how people come to make the choices they do, and whether we can make sense of them. These questions are harder to pose, and harder to answer, when the moral consequences of people's choices in situations of injustice, oppression and adversity, are ones that are not unequivocally good. Indeed, perhaps it is through confronting the uncomfortable questions raised by a reality in which 
the pursuit of morally and politically defensible goals often leads people to act in ethically troubling ways that we can enrich and expand our understanding of moral agency and its relationship with social change.

In the following discussion, I explore this possibility, beginning from the insistence that the way to address these moral questions, whether in classrooms or in philosophical discussion, is not through posing dilemmas between different courses of action as demanding an answer to the question "what would be the right thing to do?", but through an in-depth engagement with narratives of agents in situations who have made difficult, perhaps impossible choices, in impossible situations, and where the question to ask is "how can we make sense of these choices and of their ethical significance?"

Moral philosophers have addressed the value of the imagination in helping us to develop moral understanding and to nurture ethical capacities such as empathy (see e.g. Crary, 2016; Nussbaum, 1990, 1995; Warnock, 1978) Annette Baier specifically - and controversially - argues that we need to engage with the violent acts of political terrorists, for "the first step toward getting articles of peace for our condition is to put ourselves in the shoes of those driven to terrorism, to entertain the thought that there but for the lottery of history (and perhaps but for saving cowardice) go we." (Baier, 1995, p. 213). Baier's point is that questions about whether and when violent means can ever be seen as morally justifiable in the pursuit of morally just goals cannot be answered in the abstract. For "our attitudes to killing and to violent assault seem, in their baroque complexities, more amenable to historical and psychological explanation than to rational systematization and justification." (ibid, p. 209).

In what follows I focus on a situation of extreme oppression and injustice, and on a violent course of action taken by agents who are involved in this situation in different ways. In so doing, I draw on Baier's insights, and also on the work of Jose Medina, who suggests that "under conditions of oppression, the most responsible epistemic subjects tend to be precisely those who are most disadvantaged by the oppression in question, [...] they tend to exceed their epistemic duties and make epistemic contributions that (can) transform deeply the social knowledge available" (Medina, p. 187). My discussion, therefore, is intended as a contribution to the theoretical exploration of moral agency and the epistemic conditions in which it emerges. This exploration, as I have suggested, can make a significant contribution to the theoretical grounding of work in Critical Pedagogy intended to promote and pursue action for social justice. Rather than creating imaginary scenarios to engage the imagination, I rely on a rich fictional account, rooted in political and historical reality. This particular account has the further advantage of contributing to the expansion of the moral landscape of many critical educators and students in Western classrooms, where a great deal of theoretical work on Critical Pedagogy is authored and discussed, by taking us beyond the world that may be familiar to most of us.

As Baier notes (1995, p. 209), most people have the luxury of learning their attitudes to and discriminations regarding "the morality of violence" in conditions of relative privilege. Yet protest and rebellion against oppression regularly involve violence and danger to human life; dangers which will inevitably, as Baier says, "seem unjustified to many of those who have not suffered the injustices or inhumanities that are protested, and to those with limited imaginations or limited sympathy". (Baier, 1995, p. 214). Of course there is no shortage of experience of oppression, disadvantage and injustice in the contexts in which 
many critical pedagogues in industrialised, Western states are working. Nor is there any shortage, in this context, of stories of individuals and groups who have struggled to overcome and challenge such injustice. But part of what I want to explore is whether there is a value, for our philosophical and moral understanding, in reflecting not just on familiar and successful stories of struggles for social justice, but on different, often ugly and possibly terrifying stories of such struggles; struggles that may be not only terrible and painful, but, ultimately, disastrous.

I suggest that looking closely at such struggles may push us to ask some uncomfortable questions about the relationship between critical consciousness and action for social justice. I am not proposing that we reach for a theoretical resolution to these questions, but I am suggesting that asking them can push us to think deeply about important aspects of our moral and political lives, both as academics committed to the link between education and political action, and as educators concerned to encourage our students to reflect on moral values, moral agency, oppression, and resistance.

\section{Hopeful Stories}

Stories are an important element of the optimistic outlook behind the commitment to Critical Pedagogy. One reason Critical Pedagogy is such a potent and educationally significant project, maybe now more than ever, is because of its message of hope; a message that Paulo Freire frequently reiterated. Articulating how hope is bound up with critique, Freire wrote:

"Prophetic thought, which is also utopian, implies denouncing how we are living and announcing how we could live. It is, for this very reason, a hope-filled form of thought" (Freire, 2004, p. 105). This is, as many have noted, not a naive utopianism, but a commitment to collective struggles conceived as an ongoing process of becoming conscious of our presence as actors in the world. At the same time, it would not be much use defending a view of education linked to a vision of social change for the better if we did not have believable, hopeful stories - for ourselves and our students - of how collective action has succeeded in bringing about justice and freedom from oppression. Much of the literature on Critical Pedagogy and social justice education draws on such stories, some of them familiar narratives like those of the Civil Rights movement, where acts of resistance to oppressive structures had an unambiguously positive result. Important recent work by philosophers (see e.g. Babbitt, 1996; Fricker, 2007; Medina, 2013) has complicated the often simplistic picture of virtuous individuals acting bravely to challenge unjust social structures, and has developed valuable accounts of the complex ways in which epistemic, cognitive and ethical processes and experiences interact to both enable and block forms of resistance. Nevertheless, the overall message is a hopeful one: given the right conditions, collective social action can lead to critical challenges to and the eventual dismantling of oppressive structures. Indeed, a recognition of the complexity of intertwined forms of oppression and their contextuality is part of the moral imperative in much of this philosophical work. Jose Medina, for example, in exploring how Rosa Parks' act of resistance cannot be understood independently of the collective agency of the emerging social movement of resistance, concludes with the powerful argument that those of us concerned with challenging 
oppression need to "start by asking what the enabling and constraining effects are of the social contexts in which acts of resistance take place". (Medina, 2013, p. 241)

There is, then, a crucial element of hope in these narratives; yet this is not the same kind of hope that Gur-Ze'ev, in his critique of Giroux's version of Critical Pedagogy, describes as an "easy optimism". Gur-Ze'ev's concern, as Gert Biesta explains, lies with what he sees as the dangerous implications of Freire's "non-critical" preference for the self-evident knowledge of the oppressed to that of the oppressors; an "easy optimism" and "positive utopianism" that, in Gur-Ze'ev's view, risks liberatory pedagogy turning into a potentially violent form of "counter- totalitarianism." (Biesta, 1998, p. 502).

The optimism I am talking about is not that which forms the basis of Gur-Ze'ev critique, and this is not just because I want to draw attention to the point that in Freire's own writings, anger plays almost as important a role as hope. "I have the right to be angry and to express that anger, to hold it as my motivation to fight, just as I have the right to love and to express my love for the world", Freire says in Pedagogy of Indignation (2004), where, as Donald Macedo notes (in Freire, 2004, p. xi), "Freire reiterates the importance of anger as part of a constitutive matrix that must be combined with hope" (ibid) and sees anger "as an appropriate response to obscene violations of human rights and social injustices" ( $x$-xi).

The optimism that I am referring to is that implied by the very use of the familiar narratives that serve as examples of successful collective action for social change. The agents in these narratives - Rosa Parks and her fellow activists in the NAACP; the landless peasants in Brazil - take actions that are recognized not just as morally justified as means to the end of realizing the moral principle of justice; but as morally unproblematic in and of themselves. This, indeed, is the message of the humanistic core of Freire's position, reflected in Couch's (2009) rallying cry for Critical Pedagogy: "From the salt mines to Seattle, throughout history, movements such as these have challenged and deposed dictators, stopped armies, undermined corporations, established basic human rights and halted entire industries, all without the use of violence" (Couch, quoted in Ollis, 2012, p.3).

It seems almost to follow from these narratives that a genuinely humanistic, emancipatory Critical Pedagogy will bring about a form of critical consciousness that, however indignant and angry, will not lead to a form of resistance that has morally repugnant, violent elements.

I wonder, though, if we are not letting ourselves off the hook in assuming this to be true, and in investing our theoretical resources in developing pedagogical strategies for bringing about critical consciousness in our students. Do we not owe it to ourselves, and to our students, to think about situations where indignation and critical consciousness of injustice, coupled with hope, can lead to far more ethically troubling and uncomfortable forms of action? Do we not, in thinking about what justice is, how it can be furthered, what leads individuals to take action in fighting injustice, and the pedagogical aspects of such action need to think not just about apparently successful and morally uplifting struggles, but also about less obviously successful, and perhaps morally troubling ones?

If we want students who are going to be morally committed, politically engaged citizens who will act against injustice and oppression, perhaps we need to encourage them to think 
critically and deeply about moral agency and about the roots of their own moral attitudes, including their attitudes to violence. I suggest that a critical pedagogical engagement with these questions can perhaps be enriched not just through offering hopeful narratives of the triumph of moral reason and courage over fear, oppression and injustice, but through reflecting on more ethically complex and equivocal narratives, where hope and despair, moral triumph and moral failure, may be intertwined in far more complicated ways.

Two key elements of Freirian Critical Pedagogy are the notion of critical consciousness, and the significance of acting in solidarity with the oppressed. These elements have significant pedagogical aspects, both within the classroom and in broader movements. Within the classroom, teachers can engage in dialogical Critical Pedagogy so as to bring about conscientization, both amongst students from marginalised groups and amongst members of privileged groups. Freire's work in this area has been both critiqued and built on by social justice educators, often drawing on work in feminist theory and critical race theory to show the complex intersection of forms of oppression, and to theorise the pedagogical value of moments of discomfort (see Boler and Zembylas, 2003; Zembylas, M. \& McGlynn, 2012). Outside the classroom, Tarlau (2014) has described how social movement theorists draw on the idea of cognitive liberation in explaining the mechanisms through which a new consciousness of the injustice of their situation can help people engage in collective struggle for social change. Likewise, it is central to Freire's commitments that the critically engaged agent determined to dismantle oppression must fight not for the oppressed but with them, and there are obvious pedagogical aspects of the experience of working and struggling as part of a collective movement of the oppressed.

In what follows, I explore a story that shows how both these elements - critical consciousness and solidarity with the oppressed - play a central role in the life of an agent committed to acting to change an obviously unjust situation; but where the culmination of these cognitive, affective processes is not one of the triumph of justice or its success but one which, if not perhaps clearly a failure, is nevertheless very troubling.

Bill Moyer has argued that critical pedagogy is "part of a project whose purpose is to dignify people so that they become fully free to claim their moral and political agency". Inside the classroom, this means "opening up a space where students should be able to come to terms with their power as critical agents." (Moyers, quoted in Giroux, 2007, p. 1). But outside the classroom, with people who have not even been able to enter into the arena of the classroom to begin with, how does one open up such spaces? What are the moral constraints on what can constitute such opening up, and what are its possible costs? Focusing our attention on the ethical, affective and cognitive processes involved in allowing people to become fully free to claim their moral and political agency in a site of a difficult and desperate struggle, may give rise to some very uncomfortable thoughts that, while maybe not fully resolving these questions, at least forces us to seriously engage with them.

\section{The Lives of Others}

Neel Mukherjee's novel The Lives of Others (2014) centres around the Ghosh family and the rambling, complicated dynamic of their lives in the house that they all share - the grandparents, three married sons, an unmarried daughter, and a widowed daughter-in-law in Calcutta. They are a wealthy middle-class family, whose wealth has somewhat dwindled 
due to recent political instability and bad management of the family business, but who nevertheless cling to their privileged social status and invest great energy in upholding their proud position within the local community. There is a clear hierarchy within the family, and intriguing stories of love, betrayal, jealousy and inter-generational conflict. The narrative, most of which is set in 1967-68, moves between the house in Calcutta with its various inhabitants, and the central character of Supratik, who has disappeared, having, as a student, got involved in revolutionary politics. Originally part of a Marxist student group, he becomes disillusioned with their party politics and joins the Maoist Naxalites, training to go deep into the countryside and plan an armed insurgency to claim back land for the impoverished and oppressed peasants. Part of the book is written in the form of letters that Supratik writes - but never sends - to his young widowed aunt, with whom he is secretly in love, describing his experience in the movement.

Although we are not told the full story of Supratik's moral and political development, and Mukherjee leaves open the question of how he began on his journey towards political consciousness, there are several key scenes in the book that show the development of his critical consciousness and how this cognitive process interacts with affective processes in leading to his resolve to leave home and join the Naxalites. One such key scene is recalled by his mother, who, after his disappearance, collapses physically and mentally and spends her time drifting around the house trying to piece together some story that will explain why he left, where he has gone, and how she can get him to come back.

She remembers one night when Supratik came home late. He has, at that point, unbeknown to her, already become a key member of the local Maoist cell. He is often out late at meetings, and she has waited up for him, concerned about the visible changes in his behaviour:

"You're eating like a sparrow nowadays. You've hardly touched your food."

"You give me so much. There are so many dishes."

"Where so many? One dal, one fry, one vegetable dish, a bit of fish, that's it."

"And don't you think that's a lot?"

"You've eaten like this all your life", she said, baffled.

"Don't you agree we eat too much?"

"Who, you and I?" she asked, still puzzled.

"No, no, by 'we' I mean all of us, everyone in our social and economic class. Don't you think that we have lots, that we could afford to lose a bit?" The grin had disappeared and all its traces too. Those big eyes flamed with a different kind of light now.

"I don't understand what you say nowadays. We have always been like this, what's wrong with our way of eating? Everyone eats like this."

"No, not everyone eats like this, Ma." The words were cold and heavy, like stones. "Gagan, Madan-da, Lalati-da, the other people who work for us, do they eat like this?"

"Tsk, but they are servants, they eat differently."

"Can you explain to me why the servants eat differently while they live in the same house?" There was something else in his voice now, something cold and coiled. 
"This is the way it is. It has always been like this," she repeated, conscious now that she was failing to give him the right answer, the answer he was looking for. It was as if she had been forced to participate in an opaque game, the rules of which she didn't know. [...].

"And what has always been must remain that way, must always be for evermore, right?" Again, that edge of something like menace.

"I... ..don't understand what you're saying." Pause. "I don't understand you anymore."

"No, you don't". Delivered like three stabs. Then he had got up and left. (Mukherjee, 2014, p. 74)

In this scene Supratik, a member of a privileged group, is clearly articulating the kind of critical consciousness that enables him to see how his very behaviour, the rhythms of his everyday life, are part of a system that enables structural injustices to persist while at the same time masking and normalising them. Resisting this normalization is a crucial aspect of the process Freire describes as conscientization. Freire sometimes talks about this resistance in terms of a moral duty: "There is the duty, for example, to never, under any circumstances, accept or encourage fatalist positions. There is also the duty of rejecting, for that reason, statements such as: 'it is a pity that there are so many among us who go hungry, but that is what reality is.' "(Freire, 2004, p. 37).

For members of privileged groups, as many theorists have explored in a pedagogical context (see Boler, 2004; Boler and Zembylas, 2003, Zembylas and McGlynn, 2012), this process of coming to realize how what seems "normal" may in fact be only normal for one's own group, and how continuing to accept it as so can constitute a complicity in the ongoing disadvantaging of other groups, can be unsettling and uncomfortable. In a similar vein, Jose Medina (2013), drawing on the work of Miranda Fricker, Jane Adams and John Dewey, has developed an account of how "perplexity and self-estrangement are of the utmost importance for cognitive, affective, ethical and political learning; democratic sensibilities depend on them". (p. 19) In defending his notion of "epistemic friction", Medina makes a plea that could be read as a plea to educators - although he is not talking to or about teachers or schools: "By seeking these experiences of perplexity and disruption and using them as mechanisms of learning, we can cultivate a social sensibility that opens our eyes, ears and hearts to other ways of thinking, feeling and living". (ibid).

As the above scene makes clear, Supratik's critical consciousness accompanies his growing estrangement from the comfortable and familiar life of his family and their social world. His physical distaste for the lovingly prepared and delicious dishes that his mother puts before him is expressive of a kind of Wittgensteinian "seeing as" where, as Nigel Pleasants explains, "to see something 'as' something is to see what one hitherto took to be an object of a certain kind now as having qualities, relations, implications, or significance, which previously one had not seen-'I see that it has not changed; and yet I see it differently.'" (Pleasants, 2008, p. 108)

Once he has seen his family's privilege for what it is, and understood how it serves to maintain a social order in which others are prevented from obtaining anything like a similar level of material well-being, Supratik is unable to see their food simply as food. The abundant, cheerful family meals that are such a vital element of life in the Ghosh household, and that 
are described in mouth-watering detail in the novel, have become a symbol of their complicity in a deeply unjust social order; and a visceral reminder of the hunger of those who are excluded from their social world.

Yet the pedagogical aspects of this sensibility are complex. Some accounts, including Medina's, seem to suggest that this estrangement plays an important pedagogical role in the development of political understanding, as reflected in Bourdieu's remark that "Political subversion presupposes cognitive subversion; a conversion of the vision of the world..." (Bourdieu, 1982, p. 127). However, Supratik's discomfort is, one could argue, already political, for he has already been exposed to the political ideas that shape his understanding of structural injustice. What is clear, in any event, is how profoundly the emotional and cognitive aspects of this understanding affect him; so profoundly that he is no longer able to tolerate his family's comfortable life; that it becomes impossible for him to carry on living as before.

The process Supratik undergoes can also be described as a kind of cognitive liberation; important in the context of pedagogical interaction with oppressed groups who come to understand the reasons for their oppression and the possibilities for social change; but also crucial in explaining the move from critical consciousness to political action amongst members of privileged groups. As Tarlau explains: "Cognitive liberation is also similar to what Jane Mansbridge and Aldon Morris have referred to as 'oppositional consciousness' - a mental state that develops when people begin identifying with a subordinate group, articulating injustices done to that group, opposing those injustices, and seeing the group as having a shared interest." (Tarlau, 2014, pp. 379-80).

These scenes where he is increasingly unsettled by and estranged from his family's daily practices indeed form part of the narrative that makes sense of Supratik's growing political resolve and his eventual decision to leave the city and join the Naxalites to fight alongside the disenfranchised landless peasants in the poorest region of the country.

But what emerges interestingly from this scene is not just Supratik's increasing sense of discomfort with what had previously seemed familiar, but his infuriation with his mother's inability to see this. The perception that those around him are unwilling and unable to see things his way, and his realization of the impossibility of getting them and others like them to act for justice, increase both his own sense of alienation and his understanding of what is needed to bring about real justice for the people around him who are starving.

The next stage in Supratik's narrative, in fact, follows the account presented by theorists of Freire's explanation of the development of critical consciousness, where a recognition of the need to transform oppressive social structures entails that "the critically conscious individual is willing to take risks in resisting oppression" (Smith, in Roberts, 2000, p. 140).

The detailed descriptions in Supratik's letters of his time spent training with the Naxalites and then working and living with desperately poor tenant farmers, preparing the ground for collective action, paint a clear picture of his willingness to take risks. He has already risked indeed perhaps already brought about - estrangement from his family; damage to his relationship with his mother that has repercussions for his younger brother and other members of the household; he has risked the family's standing in the community and good relationship with the local police force, undermined by the suspicion that they are harbouring a Naxalite; and now he risks his own health by subjecting himself to months of back-breaking labour and near-starvation. Yet as the story goes on, the risks become more daring; their 
likely and real consequences more violent for both Supratik and those around him; and we are forced to ask ourselves: What risks are critically conscious individuals prepared to take? Could it ever be the case that their political conscience leads them to be willing to risk not just their own lives, but those of others? And if so, how can we make sense of this willingness? Is there any epistemic, experiential and emotional processes that can explain it? The impoverished tenant farmers who Supratik joins seem to fit Freire's description of people in the state of semi-intransitive consciousness:

"Their interests centre almost totally around survival, and they lack a sense of life on a more historic plane. Semi-intransitivity represents a near disengagement between men and their existence. In this state, discernment is difficult. Men confuse their perceptions of the objects and challenges of the environment, and fall prey to magical explanations because they cannot apprehend true causality." (Freire, 1974, p. 14)

The scenes of brutality and degradation at the hands of violent landowners; the dehumanizing effects of the daily struggle for the basic means of survival, leave us in no doubt as to the sheer hopelessness of the lives of the villagers. Perhaps it is also important here to reflect on the words of Franz Fanon who, commenting on the peasantry, said: "It has nothing to lose and everything to gain. The under-privileged and starving peasant is the exploited who very soon discovers that only violence pays." (Fanon, 2004, p. 23)

In living with the oppressed farmers, sharing their meagre shelter and food, experiencing the daily brutality and exploitation to which they are subjected by landowners, police and money lenders, Supratik undergoes the kind of embodied experiential learning that is so central to Critical Pedagogy. Working with the peasants in the fields, he experiences physical challenges and real hunger for the first time in his life:

His palms and fingers, after weeks of working in a paddy field with a sickle, are

"... a mad criss-cross of little cuts from the sharp, dry edges of the rice leaves and stalks [...] My hands were so sore in the morning [...] I couldn't make a fist, so I made myself make a fist ten, fifteen, twenty times with each hand. The cracks reopened and beaded with blood.... And speaking of sleep, I'd never known sleep like this before - a total wiping out of all sense, all consciousness. I hadn't known exhaustion like this before either; a bone-breaking, boneaching tiredness [...]; now I knew yet another reason why everyone in the heart of rural Bengal went to sleep so early. When you worked in the fields from six in the morning to four in the afternoon the tiredness resulting from it stunned you into silence. You went from being a human, animated by a mind and spirit, and consciousness, at the beginning of the day, to a machine without a soul at the end of those ten hours, moving your arms and legs and mouth because you felt some switch hadn't been turned off " (Mukherjee, 2014, p.145146).

Supratik's experience of the constant, gnawing presence of hunger leads to an important insight:

"The picture of starvation here, the picture that we city-dwellers carried around in our heads when we thought of rural poverty, of bony, half-naked people withering to death, was wrong - that was what happened during times of famine. In ordinary times, like now, the truth was 
different: the boniness remained, but it was no longer day after day of fasting; instead, weeks and months of hunger, of not having enough to eat, of meagreness and undernourishment and weakness." (p. 175)

Here is a case of what Medina describes as "the experiential disruptions that arise in interaction with significantly different others." (Medina, 2013, p. 19). Medina sees such disruptions as "precious opportunities for developing an awareness of our interdependence and a critical consciousness of the limitations of our perspective vis a vis others." (ibid). The pedagogical significance of Supratik's physical and emotional immersion in the lives of others, though, consists not just in an expansion of his epistemic possibilities and thus a fruitful kind of epistemic friction of the type Medina talks about as vital to democracy. It also offers a concrete example of what Freire talks about in Pedagogy of Indignation, where the indignation is deepened by a growing understanding of the economic conditions that make the peasants' lives so materially desperate.

One day, frustrated, Supratik does the maths, calculating what the farmer who he is living with should receive as his share from sharecropping each plot:

Kanu received eight ser of rice from the first plot and twelve ser from the second; a total of half a mon of rice [...]. He should have received slightly more than double the amount, just over one mon. This would feed him and his family one square meal a day for two months. (Mukherjee, 2014, p. 149-50).

The scene that follows reflects both Supratik's growing indignation and resolve to take political action, and the inability of those subjected to ongoing, dehumanizing oppression to think beyond their immediate need for survival:

Kanu said that when the midday meal was given while harvesting this plot, they discovered that the portion of rice served to each labourer had been halved. Four other workers confirmed this. There were murmurs. Then there were answers from the masters - How could you have the cheek to ask for more food...[...]

I told Kanu that I was going to deal with them. He looked ill with fear and said - Babu, then what we are getting is going to go too. Don't make that mistake. Half-stomach is better than an empty stomach... (p. 150).

Seeing Kanu's response, his fear for the lives of his wife and children, both humbles Supratik and strengthens his indignation and his resolve to act collectively with the farmers to address the injustice with which they are treated; his resolve, though, is to commit a drastic and violent act. The culmination of Supratik and his comrades' project of educating the farmers in how to organize against exploitation is an operation where they not only destroy the paperwork that is trapping them in indentured labour, but brutally murder the landlords who have been driving them to starvation and debt.

Having successfully carried out their first violent attack, the villagers who joined the struggle become visibly more hopeful and engaged, and go on to recruit others to the growing movement of resistance:

"Our four new comrades pledged their lives. Anupam said - This is not life that we have. This is a kind of death. If we die fighting so that our children can have better lives, we will die fighting". (p.307). 
Supratik and his comrades have, through their own process of critical consciousness, engaged in a collective project for social change that has, like all successful critical pedagogy, opened up a space where individuals have become fully free to claim their moral and political agency. Yet this space has morally unsettling, indeed repugnant aspects to it.

Supratik, meanwhile, continues to struggle with his own moral and political agency and the inescapable ethical dilemmas of his identity. Returning to the city after months of revolutionary guerrilla action in the countryside, he takes up residence again in the family home while he prepares for the next stage in the Naxalite strategy of resistance. Back in the Ghosh household, Madan, the family servant, is a constant reminder of Supratik's complex and conflicted loyalties.

One lunchtime, Madan lingers on, annoying Supratik with his usual "You didn't touch your food, look what you've made of yourself, all skin-and-bones..." until Supratik realises that this mantra is only an excuse; Madan is stalling for time, waiting to have a moment in private with him.

He tries to make it easy for the old man. "Do you have something to say to me?" he asks gently once the servants have departed.

Madan stands apart, at a distance from him, and say, "boro-babu" -Big Boss, that only halfironic term of affection from his childhood has fused to him; there is no hope that Madan-da is ever going to call him by his first name - "your mother has survived a lot of pain."

Supratik does not, cannot, say anything.

"We are poor people, Boro-babu, what do we know? You and your lot are educated, you've read books, been to college, will you listen to what we have to say?"

"Why don't you try?"

"Boro-babu, the world does not change, you destroy yourself trying to change it, but it remains as it is. The world is very big and we are very small. Why cause people who love you to go through such misery because of it?"

Once again, what response can he give to this?

"Your mother took to her bed after you were gone. At first she wouldn't even touch water until you returned. I've made a bargain with God, she said. She was shrivelling up like leather in the sun. I've known her ever since she came to this house as a daughter-in-law; it burned my chest to see her like that" his voice breaks.

Supratik looks up sharply. Madan-da's eyes are red with unshed tears. Supratik turns his face quickly away.

But Madan reins himself in. "What good will come of all this that you are doing?" He asks.

"What is it that you think I am doing?"

Madan answers tangentially, "Being kinder to your near and dear ones - isn't that a bigger thing that doing good for the unknown mass of people?"

A switch is flicked somewhere. It sends through Supratik a surge of cold fury that he is being given a lesson in political morality by the family's cook. His answer is like the crack of a whip: "Was that what you were doing when you prostrated yourself in front of my grandmother after grandfather's heart attack, and went and begged her to forgive you for your son's part in gheraoing him? You asked her to mete out whatever punishment she thought fit for your 
betrayer of a son. Let loose the police on him, let him go to jail, you said. Was that kindness to your near and dear ones?"

\section{[...] Supratik carries on in the face of Madan's unblinking, silent gaze;}

What, have you forgotten? As CPIT stooge, that's what you said your son was. You were right, as it turned out, but what did you think was more important - that he served your petty interests in not rocking the boat for you or that he fought for the rights of scores who have nothing?" (Mukherjee, 2014, pp. 425-427)

As A.S. Byatt notes in her review of the book, it is significant that Supratik, in spite of his political consciousness, cannot here avoid seeing Madan from his family's viewpoint, "their" cook. And his anger at Madan for lecturing him, in this capacity, while himself having begged the family to "let loose the police" on Madan's own son, the leader of the striking workers, is clearly part of what explains Supratik's resolve, soon after this, to take the ultimate risk in pursuit of his political goals; but also to commit the ultimate act of betrayal. (Byatt, 2014).

Supratik has been entrusted with drawing up the strategy for the next stage of Naxalite urban action. But now under heavy armed assault by both Congress and the $\mathrm{CPI}$, their group is in urgent need of money to finance their defence; if not, Supratik knows, they will be simply wiped out. And so he resolves to steal valuable family jewellery from his aunt's collection in order to fund the revolution. The immediate, inevitable and awful consequence of this action is that Madan, the loyal family servant who has lived with them for 60 years, is targeted by the police as the prime suspect and taken into custody. Madan is eventually released, and Supratik, identified as the mastermind behind a spate of Naxalite bombings in the city, is arrested. The final pages of the book describe the awful unravelling of the lives of all the central characters in the story; an unravelling set in motion by Supratik's actions and by his ultimate confrontation with his own conflicted identity:

"How can he answer the question that is like a vortex inside him? That it is easier enjoining others, in distant villages, to break the walls of their historical conditioning than to do the same violence to the fabric of his own social conditioning? Or can he bring himself to do both with equal ease? Can he?" (p. 434)

Although one could characterise Supratik, on the basis of earlier parts of the narrative, as someone who has already attained critical consciousness, this scene seems to support the account developed by Peter Roberts (1996), who warns against the "systematisation of the stages theory which [...] leads to a mechanical theory of consciousness, [...] which goes against the grain of Freire's dialectical perspective on reality" (p. 184). Drawing on the central Freirian notion of praxis, Roberts argues that conscientization, for Freire, is an "everevolving process" (p. 197), akin to the way in which "the pursuit of one's humanisation through praxis is [...] an inevitably incomplete process: the transformed reality which results from reflective action always presents a fresh set of (material or social) conditions, requiring further reflection." (Roberts, 1996, p. 187)

The further reflection triggered by the conditions of Supratik's life, however, has lead him to make a disturbing choice with terrible consequences for both himself and others. 


\section{Hope and Hopelessness}

Where, then, does this consideration of Mukherjee's novel leave those of us who still want to defend Critical Pedagogy, and what can it contribute to our theoretical perspectives on its central concepts and commitments?

Peter McLaren, drawing on Moylan's account of "critical utopias", talks of the important pedagogical role of articulating and defending "a yearning for what has not yet been achieved" (Moylan, in McLaren, 1994, p. 208) and of the politics of hope. But an engagement with the stories of Supratik, Kanu and countless others like them shows forcefully how in certain desperately dehumanising and oppressive situations, this yearning for what has not yet been achieved can constitute both a vital source of hope and a willingness to commit acts which themselves unsettle basic ethical commitments.

This insight is relevant not just to Supratik's own choice to put what he sees as his moral obligations to a political struggle against oppression above his moral obligations to and relationship with his family; but to the moral cost paid both by the victims of his actions and by the agents who he persuades, through his political and pedagogical interventions, to join him in the struggle. Regarding the first choice, there are echoes here of Sartre's famous description, in Existentialism and Humanism, of the apparent tension between personal morality and political struggle. Indeed the above analysis shares with Sartre the insight that the answer to the question of what is the right choice to make cannot be given a priori - for "Who can give an answer to that a priori? No one. Nor is it given in any ethical scripture." (Sartre, 1949, p. 213).

Yet what is added, I think, by a reflection on Supratik's story, is the important point that at the heart of his cognitive and affective process of developing his political consciousness and claiming his moral agency, is the uncomfortable realization that this line is impossible to draw. For by benefiting from the privilege conferred by a system of oppression, agents in positions of privilege - however "innocent" - are complicit in its perpetuation and thereby morally culpable for the suffering of others - others whose lives are mostly invisible to them. The question, then, for theorists and practitioners of Critical Pedagogy, is not just what steps are morally justified in challenging such oppression, in making such lives fully visible, but under what conditions does it become possible for agents to act to take these steps. Mukherjee's novel raises the disturbing possibility that perhaps, in situations of extreme oppression and desperation, only desperate acts allow people to enact the kind of agency required to regain their humanity.

This possibility is in fact foreshadowed in the harrowing scene that forms the Prelude to the book. Nitai Das, a tenant farmer worn down by years of degrading treatment and struggle for survival, reduced to begging from his landlord in a desperate attempt to bring home food for his wife and young children, who have not eaten for five days, goes home empty handed. In a final attempt to save them from a life of endless misery, he kills his family before taking his own life.

This story is reminiscent of the story of Sethe in Toni Morrison's novel Beloved, who kills her children rather than allow them to become slaves. As Susan Babbitt says in discussing this 
story, we can make sense of Sethe's choice as a morally responsible adult, rather than dismissing it as immoral and crazy. Yet doing so suggests that "the questions that need to be raised are questions not about her but rather about the conditions under which it does in fact become reasonable for her to do as she does". (Babbitt, 1996, p. 4). Similarly, in thinking about the agency of the starving famers in Mukherjee's novel, we have to recognize that their fundamental moral status is itself seen as questionable within the system in which they live. If we appreciate "what it means for a system of thoroughgoing subordination and degradation to deny human status to some people" (ibid, p. 5), "the question then is what kind of resistance can be justified by an understanding of such degradation?"(ibid).

Medina and others have developed an account of the important role of the social imagination in developing strategies of resistance. But for the starving farmers who Supratik encounters, the daily struggle for survival is so extreme, so conditioned by systemic violence, brutality and degradation, that it may be that this act of imagination is not possible until they have been given a real, vivid experience of agency and power. The experience itself is violent and horrific, but the narrative raises the disturbing suggestion that the strategies for collective mobilization may not have worked without it.

The novel also problematises the notion of hope. What can we say about the possibilities for learning, for moral agency, for critical consciousness, of people who are without hope; whose situation seems so hopeless and desperate that only desperate action seems possible?

In fact, the novel ends on a note of hope; yet it is a form of hope which, like the rest of the themes of the narrative, is ambiguous; mixed with anger, terror and human suffering.

After weeks of brutal interrogation at the hands of the police, Supratik, physically and mentally broken, is bundled into a police van in the dead of night. In the midst of wondering why he is being released, and in a semi-hallucinatory state, he has a vision -

...akin to a thing half-dreamed, half-experienced in the raggedy borders between sleep and waking - a vision of a near future, maybe fifty years, maybe seventy-five, a hundred, when the seeds that he and his kind have been busy sowing have grown, hidden from the human eye, or denied until ignorable, into forest cover for most of the country. It brings tears to his eyes, and, for the first time in his life, he cries moved by the possibility of fulfilment; not tears of joy, but of a kind of proleptic hopefulness. (Mukherjee, 2014, pp. 489-490).

The policemen shove Supratik out of the van, watch him stumble through the darkness for a few metres, and then shoot him in the back of the head.

The book's Epilogue, set in 2012, describes a guerrilla operation by a highly trained and tightly organized squad of Naxalites in the region of Bihar, where destitute villagers are subjected to intimidation, rape, and murder for trying to resist the control of their land by powerful landowners and mining companies acting with the backing of the military police. The group's tactics include planting IED's in the forest to blow up military vehicles. Their current operation involves dislodging a part of the railway track with wire-cutters, industrial pliers and wrenches, in order to derail a passenger train. It is a trick, the squad leader has been told, invented by a Bengali comrade called Supratik, nicknamed Pratik-da, in the late Sixties. Remarking on his "gift to his comrades", the young woman leading the operation reflects on the violence and dehumanization that has shaped her own life. 
"Every human being in this world", she thinks to herself, "wants, strives for, a better life... but they are deemed to be below that wanting and striving. Their lives are nothing, less than nothing. They are lower than animals..." (ibid, p. 503).

Throughout Freire's many essays, books, letters, and interviews, the "unfinishedness of our human condition" is referred to repeatedly as the necessary starting point for theorizing social transformation. Coming to an awareness of the "unfinishedness" of the human condition is similar to the concept of cognitive liberation: identifying a situation as unjust and subject to change. But this awareness of unfinishedness in Supratik's case leads to a conclusion at once tragic and hopeful: he is aware of the fact that his own actions have played a tiny but valuable part in the inexorable human struggle towards liberation; yet the struggle itself, as the book's Epilogue makes clear, is painful, unresolved and full of human tragedy. Supratik has reclaimed his moral agency, and has, in some small way, allowed these people to claim theirs; but at what cost?

Peter Roberts (2000, p. 109) has argued that: “On the Freirian view, taking a risk-laden, potentially contradictory, always constrained stand against oppression is almost invariably preferable to taking no stand at all."

Perhaps, as philosophers, we have not given enough attention to the question of what this means. The phrase "almost invariably" suggests that there are times when the risks are too great; the consequences too dreadful. But this is an idea that demands further exploration: Who determines when the risks are too great? Who are they too great for? And for whom is it sometimes preferable to take no stand at all? The way to approach these questions is, I have suggested, not through seeking a theoretical resolution, but through looking at tough cases where individuals make choices to act in desperate situations. Likewise, we need to reflect on Freire's idea that the critically conscious individual is willing to take risks in resisting oppression through looking at the kind of unsettling stories that confront us with difficult dilemmas about the kinds of risk that individuals involved in struggles for social justice do take, and through asking ourselves not just why and how they were able to take them, but whether they were right to do so. Again, I am not suggesting that these questions have straightforward answers, but asking them can add a valuable dimension to how we think about oppression, social justice, and individual and collective moral agency.

In 1986, the anthropologist David Fetterman published a review of Freire's The Politics of Education in the American Anthropologist. He ended his review with a troubling question:

"How is Freire's humanistic and liberating ideology reconciled with the logical conclusion of his pedagogy -- the physical violence of revolutionary change?" (Fetterman, 1986, p. 254).

My discussion may be construed as a version of this same question. Yet while I would strongly dispute its premise - that violent revolutionary change is a logical conclusion of Freire's position - I think it does hint at something important. For it is surely the case that a process of conscientization, especially in situations themselves characterized by violence, physical oppression and brutality - can sometimes lead to a conviction of the necessity for revolutionary change of a violent nature. What I want to reject, though, is the implication that this is a serious theoretical failing; one that can be resolved either by dismissing Freire's 
analysis, critique and normative framework, or by arguing that a truly Freirian dialogical, humanistic critical pedagogy can only lead to a commitment to non-violent resistance. Rather, I suggest that we need to take seriously cases in which critical consciousness does lead individuals to take terrible risks and make ethically troubling choices in their fight against oppression, and to reflect on what insights these cases can yield for our understanding of the complex picture of the connection between moral agency and political action. These are questions of profound educational significance for, as Claudia Card argues, "If oppressive institutions stifle and stunt the moral development of the oppressed, how is it possible, what does it mean, for the oppressed to be liberated? What is there to liberate? What does it mean to resist, to make morally responsible choices, to become moral agents, to develop character?" (Card, 1991, p.25).

The anthropologist's question, then, is not to be answered from a theoretical perspective outside the experience of real struggles for social justice. It may well be that, in the classrooms with which most of us are familiar and in which we hope our children will learn and our trainee teachers will teach, ethically sensitive, politically conscious educators can engage in a meaningful pedagogical process that dignifies all students as moral agents, helps them to understand the structures of oppression operating in their societies, and encourages a commitment to justice, moral indignation in the face of injustice, and the humility to listen to the voices of the marginalized and to fight with them in solidarity and in hope. But in places beyond these classrooms, places where there are no classrooms, where anger is so huge and hope so elusive, the process of coming to critical consciousness may lead to far more unsettling consequences. If Critical Pedagogy involves, amongst other things, making the classroom a place in which children can understand and develop their own moral agency and reflect on the connection between moral agency and social change, perhaps they can do so more rigorously if we encourage them to reflect not just on stories of successful struggles against oppression, but on stories of failed struggles. Perhaps critical educators can encourage students to consider the lives and actions not just of real and fictional characters like Rosa Parks and Atticus Finch, but of characters like Supratik and Nitai Das; to ask ourselves seriously how we can understand their choices and their actions, what they mean, and what their significance is in the networks of social interaction and epistemic practices that form part of the unfinished project of creating a more just world.

\section{References}

Babbitt, S. (1996) Impossible Dreams; Rationality, Integrity, and Moral Imagination, Boulder; Westview Press.

Baier, A. (1995) Moral Prejudices; Essays on Ethics, Harvard University Press.

Biesta, G. (1998) "Say You Want a Revolution... Suggestions for the Impossible Future of Critical Pedagogy," Educational Theory, 48: 4, pp. 499-510.

Boler, M. (2004). "Teaching for hope: The ethics of shattering world views." In D. Liston \& J. Garrison (Eds.), Teaching, Learning and Loving: Reclaiming Passion in Educational Practice, New York; Routledge.

Boler, M. and Zembylas, M. (2003) "Discomforting truths: The emotional terrain of understanding difference", in Pedagogies of Difference: Rethinking Education for Social Change, P. Trifonas (Ed.), New York; RoutledgeFalmer

Bourdieu, P. (1982) Language and Symbolic Power, Cambridge; Polity Press. 
Byatt, A.S. (2014) Review of Neel Mukherjee's The Lives of Others, The Guardian, $14^{\text {th }}$ May, 2104.

Card, C. (1991) "Introduction", in C. Card, Ed. Feminist Ethics, Lawrence; University Press of Kansas.

Alice Crary (2016) Inside Ethics: On the Demands of Moral Thought, Harvard University Press.

Fanon, F. (2004) The Wretched of the Earth, New York; Grove Press.

Giroux, H. (2017) "A Critical Interview with Henry Giroux",

http://www.globaleducationmagazine.com/critical-interview-henry-giroux/ accessed 6.4.17.

Fetterman, D. (1986) Review of Friere's The Politics of Education; Culture, Power and Liberation", American Anthropologist, 88: 1, pp. 253-254.

Freire, P. (2004) Pedagogy of Indignation, Abingdon; Routledge.

Freire, P. (1974) Education for Critical Consciousness, London; Bloomsbury.

Giroux, H. (2007) "Introduction", in McLaren, P. et al (Eds) Critical Pedagogy; Where Are We Now? New York; Peter Lang.

McLaren, P. (1998), "Revolutionary Pedagogy in Post-Revolutionary times: Rethinking the Political Economy of Critical Education", Educational Theory, 48: 4, pp. 431-462.

McLaren, P. (1994) "Postmodernism and the Death of Politics: A Brazilian Reprieve", in McLaren and Lankshear (Eds) Politics of Liberation; Paths from Freire, London; Routledge.

Medina, J. (2013) The Epistemology of Resistance, Oxford; Oxford University Press.

Mukherjee, N. (2014) The Lives of Others, London; Chatto and Windus.

Nussbaum, M. (1995) Poetic Justice: the Literary Imagination and Public Life. Boston: Beacon.

(1990) Love's Knowledge; Essays on Philosophy and Literature, Oxford: Oxford University Press.

Ollis, T. (2012) A Critical Pedagogy of Embodied Education, New York; Palgrave Macmillan.

Pleasants, N. (2008) "Institutional Wrongdoing and Moral Perception", Journal of Social Philosophy, Vol. 39, No. 1, pp. 96-115.

Roberts, P. (2000) Education, Literacy, and Humanization: Exploring the Work of Paulo Freire, Westport; Bergin and Garvey.

Roberts, P. (1996) "Rethinking Conscientisation", Journal of Philosophy of Education, 30: 2, pp. 179-196.

Sartre, J. P. (1949) Existentialism Is a Humanism, in R. Solomon (Ed.), Existentialism, Oxford: Oxford University Press.

Tarlau, R. (2014) "From a Language to a Theory of Resistance: Critical Pedagogy, The Limits of 'Framing,' and Social Change", Educational Theory, 64: 4, pp. 369-392.

Warnock, M. (1978) Imagination, University of California Press.

Zembylas, M. \& McGlynn, C. (2012) “Discomforting pedagogies: Emotional tensions, ethical dilemmas and transformative possibilities", British Educational Research Journal, 38:1, pp. 41-59. 